\title{
Research on the Impact of Strategic Human Resource Management on Enterprise Performance
}

\author{
Xi-mu Yan, He Liu and Xue Gao \\ Qinhuangdao Institute of Technology, Qinhuangdao, Hebei, China \\ Lwdxdf3@126.com
}

\begin{abstract}
Human resource is the core of strategic resources. More and more scholars start to pay attention to the strategic value of human resources and strategic human resource management. This paper discussed the mechanism that strategic human resource management improve firm performance, and put forward that occupation-development and employee training plan, pay-forperformance, temporary staff management and encouraging employees participation in the management decision-making of firm were potential smoother between strategic human resource management and firm performance. This paper carried on the empirical research on the relationship between strategic human resource management, occupation-development and employee training plan, pay-for-performance, temporary staff management and firm performance based on the human resources management data from 874 Chinese enterprises. We found that strategic human resource management had a positive influence on firm performance, and the relationship between strategic human resource management and firm performance would be moderated by occupationdevelopment and employee training plan, pay-for-performance, temporary staff management.
\end{abstract}

Index Terms - Strategic Human Resource Management; Occupation-development and Employee Training Plan; Firm Performance; Moderating Effect; Structural Equation Model

\section{Introduction}

With the development of the practice of human resource management, strategic management scholars and practitioners are increasingly concerned about the human resources. Because human resource acquisition, development and retention is embedded in their unique history and culture, so it is the the source of enterprise special competitive advantages. In order to realize the strategic value of human resources, management and operation of human resources must have strategic orientation, and enterprises need the strategic human resource management. In the course of 115 subsidiary companies from 89 Fortune 500 companies by Martell and Carroll, it has been found that to some extent, $40 \%$ to $69 \%$ of the company's human resources departments are in the process of enterprise strategic management.

Research on Strategic Human Resource Management on enterprise performance is always an important issue in the study of human resources management. Wright andSnell (2001) argues that through the strategic human resource management, the enterprises influence the behavior of enterprise human capital stock and guide employees, thereby affecting the performance of the enterprise.

Zhao Shuming (2007) studies show that, through the cultivation of strategic human resource management with the organization strategy of employees' ability, promoting the staff behavior and organizational goals, and create the core knowledge to improve the performance of the enterprise. Yang Hong (2007) believes that the strategic human resource management will change the enterprise staff characteristics and shape the corporate culture of innovation, in order to improve the enterprise knowledge creation, so as to improve the enterprise performance. Wei Liqun (2008), that of strategic human resource management through human resource management and enterprise strategy formation and development in the enterprise culture, and enhance corporate performance. Million and (2009) study shows that human resource is the carrier of innovation, strategic human resource management can make the enterprise obtain with the strategic goal of enterprise human resources for enterprise innovation, and innovation performance. Song code (2009) that the enterprise strategic human resource management in the enterprise will create innovative atmosphere, motivate employees to take risks and implement more active "active" market, development strategy, promote the enterprise innovation. The design and implementation of business strategy, build long-term competitive advantage of enterprises. Li Xuefeng, Jiang Chunyan (2011) based on the system theory that different institutional environment, the degree of the enterprise strategic human resource management on enterprise performance, unfair competition environment will hinder strategic human resource management have a positive effect on corporate performance, and the government support has been enhanced significantly between enterprise performance and the strategic management of human resources role in promoting. In this study, on the basis of the previous research, to investigate the influence mechanism of strategic human resource management on enterprise performance through staff training plan, career development and staff performance salary, temporary staff management and other typical in management practice.

\section{Conceptual Model and Research Hypothesis}

Huselid put forward that so called "best practices" human resource practices are often better than other human resource practices, so as to promote the improvement of organizational performance. Strategic human resource management effectiveness requires employees to actively participate in the practice of enterprise management. Employees to actively participate in the organization of business to expand the autonomy of employees, by stimulating the intrinsic demand increased employee engagement. Therefore, let the staff to participate in enterprise management practice, improve the 
enterprise strategic participation and their own ability, so as to make the enterprise through effective strategic management to strategic human resource management is the effective supplement.

\section{A. Occupation Development and Employee Training Plan}

The unique enterprise human capital is the fundamental source of competitive advantage (Barney, 1991). In order to cope with the changing environment and obtain sustainable competitive advantage, firms must develop flexible human capital, in order to adapt quickly to changes in corporate strategy may occur (Wright andSnell, 1998). Occupation development plan to expand the ability of employees, provide support for the development of occupation. Employee training plan so that employees have the opportunity to obtain the skills and knowledge to improve performance. Through the training program for career development and employee, employee contact to a wide range of knowledge and ideas, so that they no longer resist change, and more willing to accept new knowledge and creative (Beugelsdijk, 2008). In this regard, rich professional development and training for the implementation of the strategy of expansion of the human resources, and help enterprises to flexibly adjust the human resources to meet the various needs of the strategy (Takeuchi, Wakabayashi \& Chen, 2003). Therefore, the training plan and employee occupation development to expand the positive effect of strategic human resource management on enterprise performance.

\section{B. Implementation of Performance Pay Schemes}

In order to effectively implement the strategy of human resources, enterprises must adopt some measures to make the intention to understand the strategic level employees. The most effective and direct measure is performance pay plan, which will be the interests of individual employees and business goals are combined by wages and employee performance mode. Therefore, through the performance pay plan, human resources management can shape the behavior and attitude of employees, make it fully compatible with the strategic goal of the enterprise (Keizer, 2011). Performance pay program also supports other elements of high involvement work practices, such as union participation, temporary staff management, occupation development and employee training plan etc.. No salary support, other elements may not be able to fully support the human resource strategy. Because of the lack of incentive mechanism, the implementation of staff may be reluctant to participate in the new strategy, not with the temporary working group, to participate in the new training. Therefore, the enterprise must be the implementation of pay for performance as an important part of human resource strategy.

\section{Temporary Staff Management}

In recent years, some research pointed out that the temporary staff can also become a strategic asset of enterprises. Lepak and Snell (2002) of different employment mode that enterprises should adopt different mode of the strategic use of the human resources of enterprises. They think that for temporary staff management, there are two modes are available: temporary employment contracts and alliance. In the temporary employment contract mode, if needed by the enterprise human resources is not very important or unique, enterprises can consider hiring highly skilled contract workers, because they may cost is relatively low, but also the formation of a competitive threat to employees, motivate them to work hard and improve work performance. In the alliance, enterprises and temporary staff to establish a partnership, the specialized skills, knowledge and specific achievements specially used for the enterprise. Lepak, Takeuchi and Snell (2003) studies have shown that the use of temporary staff to improve the financial performance of the enterprise. If the development of enterprises in the internal core employees plan has made long-term investment, temporary staff quality is effectively reduced the potential risk of the enterprise core staff to leave, even if they leave, the enterprise can also result in the shortage of human capital quickly adjust and buffer. In addition, Dyne and Ang (1998)'s research shows that when the enterprises to actively invest in the temporary workers, temporary workers are also likely to have high loyalty and job involvement. They found an interesting phenomenon, a temporary employee loyalty and job involvement showed prosocial organizational behavior and enterprise long-term employees of enterprises (also called organizational citizenship behavior). Bidwell (2009) compared the use of some financial institutions, the Information Technology Department of contract and formal staff found that these institutions, managers are more willing to use contractors to complete the work. In addition, Kwon (2004) investigated the use of 182 South Korean companies to contract and related effects. The results showed that the productivity of enterprises, turnover and operating profit of a temporary staff effective management system will have an impact. Therefore, if the enterprise will be temporary staff as an important business partners, and support their career development, temporary staff can also be used as valuable resources to improve the competitiveness of enterprises (Felstead \& Gallie, 2004).

In a word, the temporary workers with professional skills and knowledge for the enterprise, and some may not have formal internal staff, thus has the very high value to the enterprise, the formation of an effective supplement to the knowledge and ability system of enterprises. Therefore, the temporary staff management system can help the enterprise to obtain the competitive advantage, improve business performance, at the same time with the implementation of temporary staff working in turn supports human resources strategy.

\section{Empirical Study}

\section{A. Study Sample Characteristics}

The number of employees in each industry the sample of this study comes from the east of China, the Central City West, more than 1245 enterprises 100, a total of 1245 questionnaires. Questionnaires were made to the development of enterprises and the development status of the industry are more familiar with the staff. 1027 copies of questionnaires, the recovery rate of the questionnaire was $82.49 \%$, of which 874 
valid questionnaires, the questionnaire recovery rate was $85.10 \%$. The eastern region has 338 enterprises, accounting for $38.67 \%$; the central region of 298 enterprises, accounting for $34.10 \%$; West Enterprise 238, accounting for $27.23 \% .118$ foreign-funded enterprises, accounting for $13.47 \%$; in the joint venture enterprises 205, accounting for 23.46\%; 332 private enterprises, accounting for $37.99 \%$; 219 state-owned enterprises, accounting for $25.08 \%$.

\section{B. Variable Measurement and Reliability Analysis}

The measurement of variables in part by Likert five scale method to make. In order to ensure the validity and reliability of measurement, the research is carries on the corresponding modification based on small sample survey. Strategic human resource management with reference to Hyondong Kim and Sung-Choon (2011) of the study, including 6 items, the scale of the Cronbach's alpha reliability coefficient was 0.89 (alpha reliability greater than 0.7 are acceptable); measurement of the main reference HyondongKim temporary staff management research (2011), including 4 items. The scale of the Cronbach's alpha reliability coefficient was 0.87 ; career development and employee training is the average number of participation in formal employee career development and staff training project; performance salary scheme for enterprise staff performance salary average percentage of the total wage; enterprise performance is mainly used for business profits measure. At the same time, the year of establishment and firm size as control variables.

\section{Research Method and Results}

First of all, using structural equation analysis method to get the path coefficients between the variables. strategic human resource management, training, career development and staff performance salary, temporary staff management has significantly positive effect by using the hierarchical regression analysis to verify the research hypothesis on enterprise performance. Occupation training, development and performance salary, temporary staff management of strategic human resource management and enterprise performance relationship between the two regulatory effectiveness through the use of Baron and Kenny (1986) adjust the utility model validation procedure is presented to verify. Because of the great differences between different variables, the numerical interval is not a, so before we need to adjust the utility analysis, all the variable data standardization. The min-max standard (standard deviation) for the effects of the following two steps: first, the direct use of the independent variables on the dependent variable regression analysis (M1 model); then, the design variables and the control variables are calculated by the interaction factor, and added to the independent variables for regression analysis (model M2). If the R2 value is greater than the M2 model M1 model R2, and the independent variables and the interaction factor regression coefficient is significant, then the effectiveness of regulation exists; if not satisfied at the same time, there is No.

Effects analysis of performance pay plan, R2 increased by 0.2 , and at the same time, the independent and interactive factors were at a confidence level of 0.01 and 0.05 significantly, therefore, there is a positive impact on the effectiveness of regulation to implement strategic human resource management and enterprise performance of the two performance pay plan, assumption 2 is validated. The system of temporary staff management regulation of utility analysis results.R2 increased by 0.23 , at the same time, the independent and interactive factors were at a confidence level of 0.01 and 0.05 significantly, therefore, the system of temporary staff management and positively related to strategic human resource management and enterprise performance of the two has regulated utility, assumption 3 is validated.

The assumption 1, assumption 2 and hypothesis 3 have been verified, therefore, the relationship between vocational training programs, the development and performance of employees, temporary employees salary management and positive influence on strategic human resource management and enterprise performance two the effectiveness of regulation. At the same time, we can see that the effectiveness of regulation training plan, career development and staff performance salary, the size of the temporary staff management, including training plan career development and staff, temporary staff management of performance pay program minimum.

\section{Research findings and discussion}

Human resource is the core strategic resources, enterprise human resources management activities should be integrated into the enterprise management strategy. However, the strategic human resource management activities are not under any and all circumstances can effectively play the role of corporate human resources strategy is not under any circumstances can the effective implementation. It is well known that no staff support and investment, it is difficult to implement human resources management strategy of enterprises. Actively participate in employee's situation, strategic human resource management and more able to play their effectiveness. Although the literature of strategic human resource management allows us to recognize the value of integration into the enterprise strategic management of human resources management, but relatively few of research on the mechanism of integration of human resources management and business strategy to improve the performance of enterprises. This study first discusses the mechanism of strategic human resource management to improve enterprise performance, that the training plan, occupation development and performance of employees, temporary employees salary management three activities for employees to participate in the decision of enterprise management, is a potential regulator of the relationship between strategic human resource management and corporate performance. Then, the activities of human resource management of enterprises in our country to conduct the investigation and study, carries on the empirical validation of the above theory to obtain the subjective and objective, strategic human resource management, training, occupation development and staff performance salary, temporary staff management will have a positive impact on enterprise performance. 
At the same time, the relationship between occupation training, development and performance salary, temporary staff management and positive influence on strategic human resource management and corporate performance the existence of the two effects, including training plan and employee occupation development regulation of utility maximization, the temporary staff management, performance pay program minimum.

This study also has some limitations. For example, some of the data is the study of subjective data, and has not conducted a detailed study of the various regions of China, which will be the next step for the research to be perfect.

\section{5. conclusion}

Human resource is the core of strategic resources. More and more scholars start to pay attention to the strategic value of human resources and strategic human resource management. This paper discussed the mechanism that strategic human resource management improve firm performance, and put forward that occupation-development and employee training plan, pay-for-performance, temporary staff management and encouraging employees participation in the management decision-making of firm were potential smoother between strategic human resource management and firm performance. This paper carried on the empirical research on the relationship between strategic human resource management, occupation-development and employee training plan, pay-for-performance, temporary staff management and firm performance based on the human resources management data from 874 Chinese enterprises. We found that strategic human resource management had a positive influence on firm performance, and the relationship between strategic human resource management and firm performance would be moderated by occupation-development and employee training plan, pay-for-performance, temporary staff management.

\section{References}

[1] Wright PM, Dunford BB, Snell SA. Human resources and the resource based view of the firm. Journal of Management,2001,27 (6):701 - 721.

[2] Huselid.M. A. The impact of human resource managemen tpraetices on turnover, productivity and corporate financial performance. Aeademy of Management Journal, 1995, 38(3):635 - 672.

[3] DelaneyJ. M. and M. A. Huselid. The impact of human resource management praetices on perceptions of organizational performance. Aeademy of Management Journal. 1996, 39(4):949 - 969.

[4] Delaney, J. T., \&Huselid.M, A. The impact of human resource management Practices on perceptions of organizational performance. A Cademy of Management Joumal,1996(4):949-969.

[5] Wright PM ,McMahan GC, Theoretical Perspectives for Strategic Human Resource Management. Journal of Management. 1992,18(2):295 -320. 